International Journal of Physical Sciences and Engineering
Available online at http://sciencescholar.us/journal/index.php/ijpse
Vol. 2 No. 2, August 2018, pages: 79 87
e-ISSN : 2550-6943, p-ISSN : 2550-6951
https://doi.org/10.29332/ijpse.v2n2.154

\title{
Ballast Treated with Asphalt Emulsion, Megarok and San Jose. AASTHO Standards
}

\begin{abstract}
CrossMark
Maria Isabel Zambrano Meza a, Edwin Alexander Rodriguez Veliz bethsy Anchundia Anchundia c, Gema Cayetano Lucas ${ }^{\mathrm{d}}$, Gema Flores Ormaza ${ }^{\mathrm{e}}$

Article history: Received 9 February 2018, Accepted in revised form 1 June 2018, Approved 31 July 2018, Available online 6 August 2018

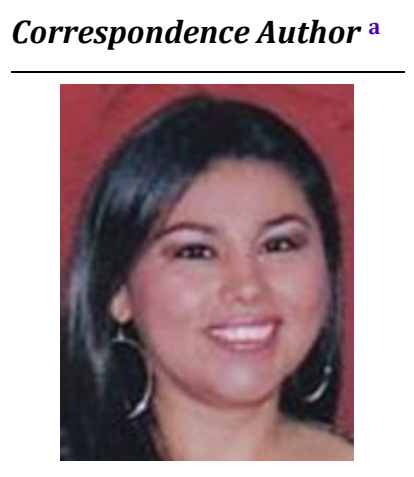

Keywords

Asphalt emulsion;

Ballast;

Abstract

In the research work, the results obtained at the laboratory level of the lending material (ballast) treated with asphalt emulsion from the quarries "Megarok and San José" are compared, applying the AASTHO standards. The quarries are located in the Picoazá-La Sequita parish of the Portoviejo canton. Samples from both quarries were evaluated in the laboratory and it was possible to carry out tests of natural humidity, Atterberg, granulometric, compaction, and soil bearing capacity (CBR). Based on the results obtained, they were compared by disclosing which of the quarries meets the appropriate conditions within the construction standards and techniques, in order to stabilize the material with asphalt emulsion; in addition to comparing it with the specifications of the AASTHO standards and the MTOP standard. The result was that the materials extracted from the quarries do not meet the technical specifications; but when mixed with the asphalt emulsion, the Megarok material fulfills as type A base.
\end{abstract}

Materials;

Pavements;

Quarries;

e-ISSN: 2550-6943, p-ISSN: 2550-6951 ๑Copyright 2018. The Author. SS Journals Published by Universidad Técnica de Manabí. This is an open-access article under the CC BY-SA 4.0 license (https://creativecommons.org/licenses/by-sa/4.0/) All rights reserved.

a MsC, Candidate to PhD, Engineering, Faculty of Mathematical, Physical and Chemical Sciences, Universidad Tecnica de Manabí, Portoviejo Ecuador

b MsC, Candidate to PhD, Engineering, Faculty of Mathematical, Physical and Chemical Sciences, Universidad Tecnica de Manabí, Portoviejo Ecuador

c Graduate of the degree and Civil Engineering of Faculty of Mathematical, Physical and Chemical Sciences, Universidad Técnica de Manabí, Portoviejo Ecuador

d Graduate of the degree and Civil Engineering of Faculty of Mathematical, Physical and Chemical Sciences, Universidad Tecnica de Manabí, Portoviejo Ecuador

e Civil Engineering of Faculty of Mathematical, Physical and Chemical Sciences, Universidad Tecnica de Manabí, Portoviejo Ecuador 


\section{Contents}

Abstract

1. Introduction

2. Research Method

3. Results and Analysis

4. Conclusion

Conflict of interest statement and funding sources...

Statement of authorship

Acknowledgements

References

Biography of Authors

\section{Introduction}

The deposits that are currently used in Portoviejo are Megarok and San José, which are located in the Picoazá parish of the Portoviejo canton. In very ancient periods the roads were traced by the passage of the animals, one of the main drivers of The construction of roads and aqueducts was the Roman Empire. The most important legacy that the Roman civilization left us was Law and public works.

The roads are the busiest areas at present, where more people are traveling daily, in Portoviejo there are different quarries that could be used in the construction of these roads, but for this, you need to make studies that allow knowing the characteristics of the material [1]. At present, asphalt mixtures are already being used in the construction of road surfaces, either in rolling layers or in lower layers and their function is to provide a comfortable, safe and economical bearing surface for the users of the roads, providing the circulation of the vehicles, apart from sufficiently transferring the loads due to the traffic to the Esplanade so that they are supported by it [2].

In recent years in Ecuador there has been significant growth in terms of infrastructure, especially in road infrastructure, which is why it is necessary to have strategies to keep the communication channels and keep them operational in optimal conditions of functionality, since the investment represented by the construction of a road is very high and it is expected that it will meet its useful life for which it was designed, the technology most used in the maintenance and construction of pavements [3]. In the province of Manabí, especially Portoviejo in its territory has different quarries to extract material for the construction of roads, the objective of this work is aimed at characterizing the lending material (ballast) of the quarries of Megarok and San José; and compare them with material mixed with asphalt to establish the characteristics of these for the construction of resistant roads [4].

The granular material is formed by a set of solid particles of different sizes, where its coarse particles from a mineral skeleton once compacted and whose resistance depends mainly on internal friction. Internally this type of matter presents in its composition the three states: solid, formed by the material coming from the stone; liquid, due to the presence of water; and gaseous, through intergranular spaces filled with air.

An important characteristic is that the granular matter tends to dissipate rapidly the energy of its particles due to the force of friction, which gives rise to phenomena of great importance as the avalanches [5]. The bases and sub-bases of the flexible road pavements are formed by non-agglomerated granular materials. When it is required to improve the behavior of these materials, due to their placement on roads with heavy traffic, agglomerated or treated materials are used [6]. The base plays an important role in the structure of any pavement as in one way or another will give security and stability within the useful life of the same, so it should also be protected so that it does not suffer deformations such as swelling or cracking that is due to a bad compaction of the soil where the pavement is going to be made [7].

The formulation of sub-base for pavement structure through the use of granular materials treated with asphalt emulsion is a little-developed study in our environment, it shows the importance from a technological point of view highlighting the important variables in the manufacture of the Asphalt emulsion in the road asphalt process. The aggregates that are used in a wear coefficient should be maximum $50 \%$ according to the Los Angeles abrasion test and the portion that passes through the No. 40 should have a plasticity index of less 
than 6 and a maximum liquid limit of 25 with a support capacity will correspond to a CBR equal to or greater than $30 \%$ [8].

Emulsions have a number of advantages over hot or reduced asphalt, so it is important to extend the use of this type of technology to the size of your network; so not only does it only provide savings in the asphalt process of the road but also improves the adhesion of the asphalt with the granular material, with a consequent increase in the life time of the asphalt folder and greater safety for the user of it [9]. It is known as the treatment of soils or granular materials to the set of procedures that allow improving some of the properties of these materials, by incorporating an additive, which can be an asphalt emulsion, cement or a chemical compound [10],[16].

This work is carried out through the comparative analysis by means of a result obtained at the laboratory level to the loan material (ballast) treated with asphalt emulsion from the Megarok and San José quarries of the Picoazá parish of the Portoviejo Canton. In these quarries, several investigations have been developed, which have allowed creating a source of information for the development of the pavements and the bases in the province of Manabí [11], [12],[15]

\section{Research Method}

A field study was carried out, extracting the samples from the San José and Megarok quarries, these were analyzed in the soil laboratory to be analyzed with the corresponding tests for a soil study. Among them were evaluated: natural humidity, Atterberg limits, granulometry, abrasion, Proctor, CBR, the percentage of wear presenting its different properties.

The necessary equipment to perform the tests for the sample (tare, proctor cylinder, CBR cylinder, large house, router, balance, glass sheet, oven, among others.), Was complied with the procedure of the regulations for use in carrying out the tests, making known that the results obtained to comply with the current standards of granulometry, AASTHO, SUSC for the classification of base and subbase.

\section{Results and Analysis}

The roads are the busiest areas at present, where more people move daily from Portoviejo, in the area, there are different quarries that could be used in the construction of roads, but for this, it is necessary to make studies that allow knowing the characteristics of the material [13]. At present, asphalt mixtures are already being used in the construction of road surfaces, either in rolling layers or in lower layers and their function is to provide a comfortable, safe and economical bearing surface for the users of the roads, providing the circulation of the vehicles, apart from transferring sufficiently the loads due to the traffic to the Esplanade so that they are supported by it [13].

The granular material is formed by a set of solid particles of different sizes, where its coarse particles from a mineral skeleton once compacted, the resistance depends mainly on the internal friction, where the matter presents in its composition the three states: solid, formed for the material coming from the stone; liquid, due to the presence of water; and gaseous, through intergranular spaces filled with air. A characteristic of the material is to be granular and tends to rapidly dissipate the energy of its particles due to the friction force, which gives rise to risk phenomena such as avalanches.

The investigation is carried out through the comparative analysis of the results obtained at the laboratory level of the lending material (ballast) treated with asphalt emulsion from the Megarok and San José quarries, in table 1 , the amount of clay mixed with the two materials.

Table 1

The quantity of clay mixed with different materials

\begin{tabular}{cccc}
\hline Quarry & $\begin{array}{c}\text { Clay } \\
(\mathrm{g})\end{array}$ & Material & $\begin{array}{c}\text { Asphalt emulsion } \\
(\mathrm{g})\end{array}$ \\
\hline Megarok & 6000 & ballast & 7 \\
San José & 6000 & ballast & 7 \\
\hline
\end{tabular}

\footnotetext{
Meza, M. I. Z., Veliz, E. A. R., Anchundia, B. A., Lucas, G. C., \& Ormaza, G. F. (2018). Ballast treated with asphalt emulsion, Megarok and San Jose. AASTHO standards. International Journal of Physical Sciences and Engineering, 2(2), 79-87. https://doi.org/10.29332/ijpse.v2n2.154
} 
In the study of the sub base, sieves of different sizes $(76.2,50.4,38.1,4.75,0.425,0.075 \mathrm{~mm})$ were used to check if the clays complied with the regulations that are used as the bases and subbases, these were divided into three classes to know the maximum and minimum values and be compared with the results obtained from the mixtures for the sub-base. Table 2 shows the granulometric specifications of the AASTHO standards.

Table 2

Granulometric specifications of the sub-base

\begin{tabular}{ccccccc}
\hline \multirow{2}{*}{ Sieves } & \multicolumn{2}{c}{ Class 1 } & \multicolumn{2}{c}{ Class 2 } & \multicolumn{2}{c}{ Class 3 } \\
& Maximum & Minimum & Maximum & Minimum & Maximum & Minimum \\
\hline 76,2 & & & & & 100 & 100 \\
50,4 & & & 100 & 100 & & \\
38,1 & 100 & 100 & 100 & 70 & & \\
4,75 & 70 & 30 & 70 & 30 & 70 & 30 \\
0,425 & 35 & 10 & 40 & 15 & & \\
0,075 & 15 & 0 & 20 & 0 & 20 & 0 \\
\hline
\end{tabular}

The graph of Figure 1 shows the results obtained for class 1 , where the maximum and minimum percentage values appear compared to the samples passed in each sieve.

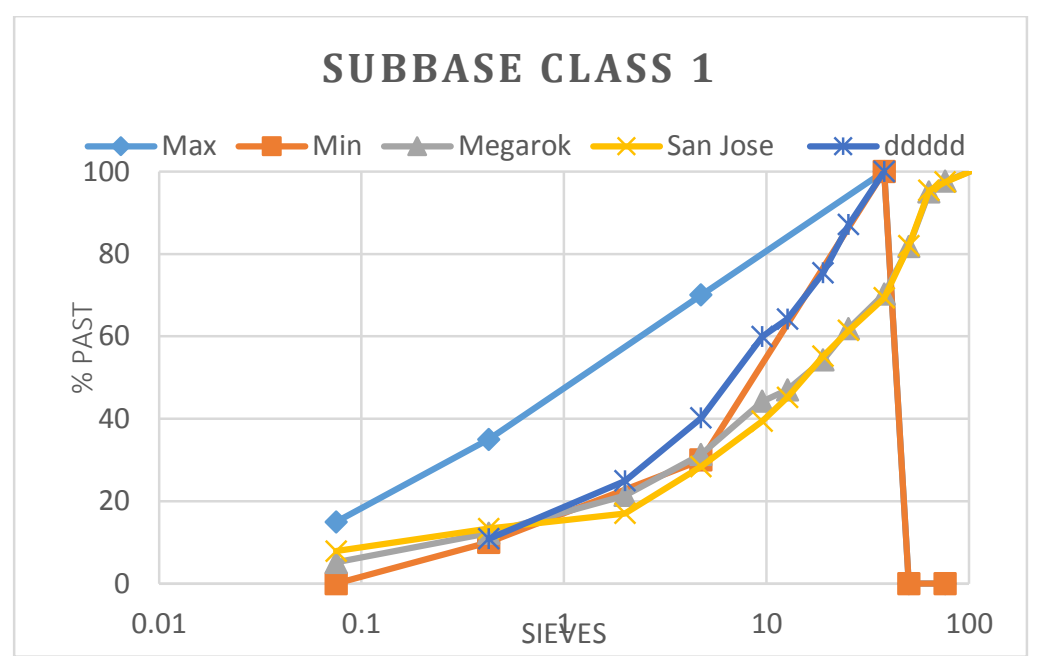

Figure 1. Maximum and minimum values obtained from the sub-base class 1

It can be described that the samples obtained from the clays studied do not comply with the granulometric regulations, proceeding to carry out other studies for the structure of the pavement. Figure 2 (A) shows the values obtained for class 2 and in figure 2 (B) for class 3; with the thicker sieves it has been noticed that it also does not comply with the AASTHO regulations 

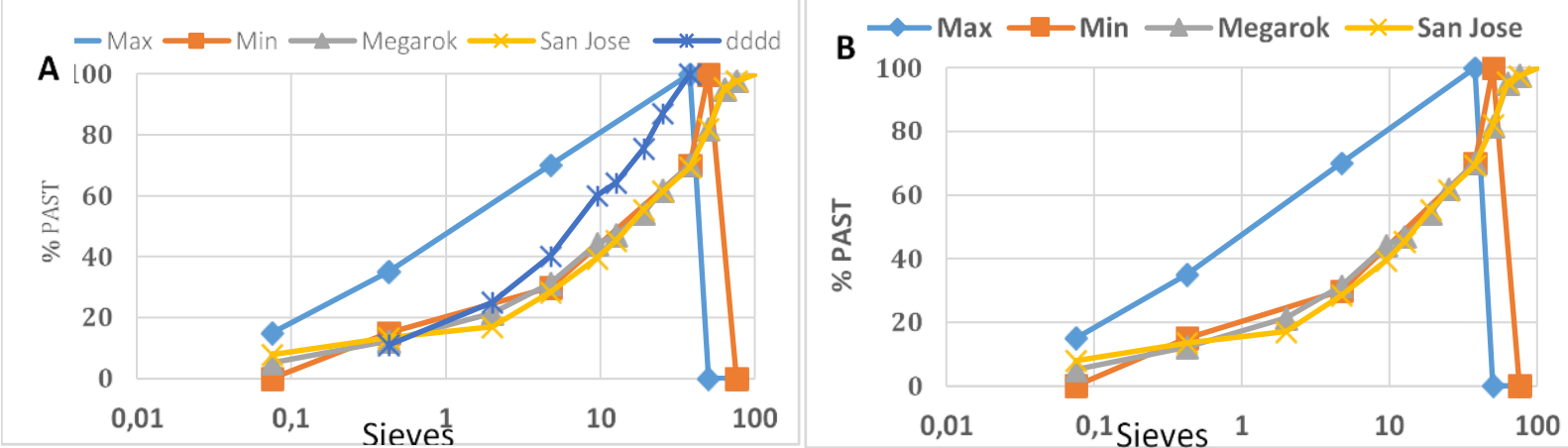

Figure 2. Deductions obtained for the subbase class 2 (A) and class 3 in (B)

Table 3 states the different percentages that pass through the square mesh of the base with its proper screen opening

Table 3

Specifications granulometric of the base

\begin{tabular}{|c|c|c|}
\hline \multirow[t]{2}{*}{$\begin{array}{l}\text { Sieve } \\
(\mathrm{mm})\end{array}$} & \multicolumn{2}{|c|}{$\begin{array}{c}\text { Percentage by weight that passes through the shades } \\
\text { of square mesh (\%) }\end{array}$} \\
\hline & Kind A & Kind B \\
\hline $2 "(50.4)$ & 100 & -- \\
\hline 11/2" (38.1) & $70-100$ & 100 \\
\hline $1 "(25.4)$ & $55-85$ & $70-100$ \\
\hline 3/4" (19.05) & $50-80$ & $60-90$ \\
\hline 3/8"' (9.525) & $35-60$ & $47-75$ \\
\hline $\mathrm{N}^{\circ} 4(4.75)$ & $25-50$ & $30-60$ \\
\hline $\mathrm{N}^{\circ} 10(2.00)$ & $20-40$ & $20-50$ \\
\hline $\mathrm{N}^{\circ} 40(0.425)$ & $10-25$ & $10-25$ \\
\hline $\mathrm{N}^{\circ} 200(0.075)$ & $2-12$ & $2-12$ \\
\hline
\end{tabular}

Figure 4 (A) shows the results obtained for the base type A and in figure 4 (B) for the base type B, with thicker sieves, noting that it complies with the granulometric standards and AASTHO
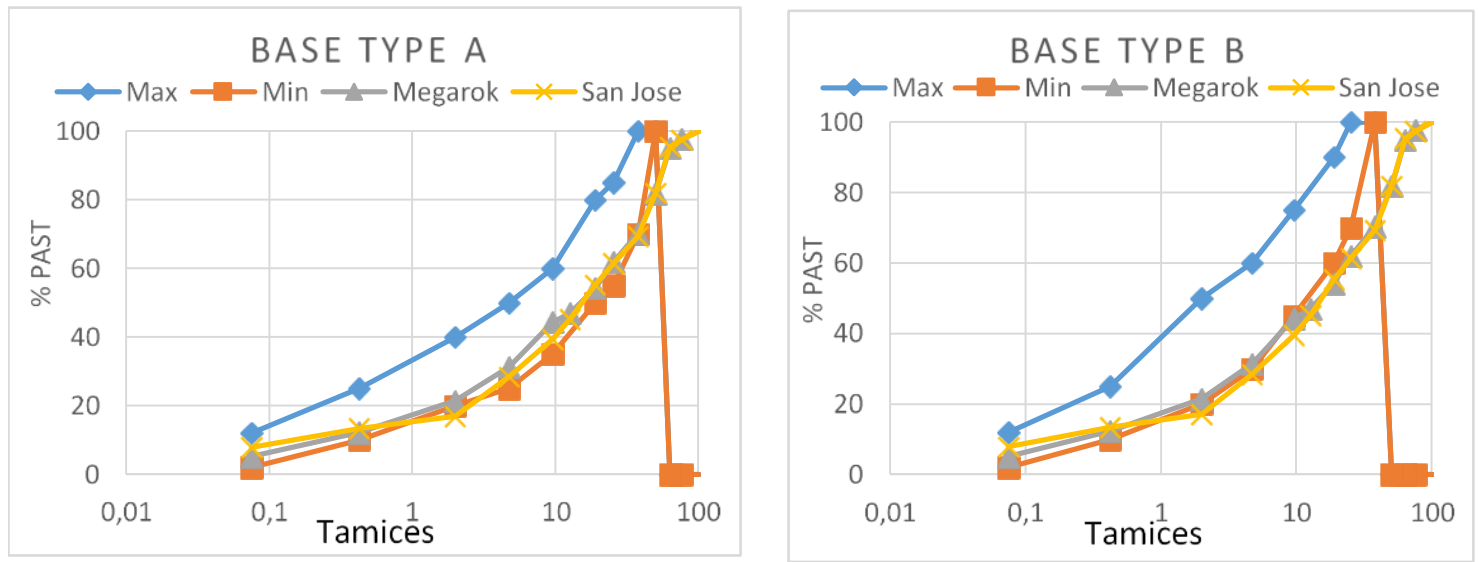

Meza, M. I. Z., Veliz, E. A. R., Anchundia, B. A., Lucas, G. C., \& Ormaza, G. F. (2018). Ballast treated with asphalt emulsion, Megarok and San Jose. AASTHO standards. International Journal of Physical Sciences and Engineering, 2(2), 79-87. https://doi.org/10.29332/ijpse.v2n2.154 
When this research was carried out, the material from the Megarok and San José quarries was found to be in breach with the specifications of the sub-base material for different classes $(1,2,3)$. In the base type A and type $B$, the observed values of both quarries coincide roughly with the minimum value of the granulometric spindle, the evaluations have obtained good results, verifying their usefulness in the construction as a base type A for the structure of the roads

\section{Conclusion}

Through the analysis of loan material (ballast) in the natural state of the Megarok and San José quarries, it was identified that this does not comply with the granular subbase according to the technical specifications of the MTOP.

The material stabilized with asphalt emulsion reached an immense percentage increase in resistance, prevailing that established in the specifications with a value greater than $30 \%$ of C.B.R. The differentiation between the materials do not meet the conditions so that they are not perfectly favorable for their use, in the pavement structure, however, one of them meets certain technical specifications that allow their use as loan material being this extracted from the quarry Megarok.

Conflict of interest statement and funding sources

The authors declared that they have no competing interest. The study was financed by personal funding.

Statement of authorship

This research is original and prepared by the authors present in the article.

\section{Acknowledgments}

The authors would like to thank the editor of IJPSE for their support, valuable time, and advice. 


\section{References}

1. Flores Rangel, J. A. (2015). Infraestructura carretera: construcción, financiamiento y resistencia en México y América Latina. Revista Transporte y Territorio, (13).

View in (Google Scholar)

2. BRACHO, C. (2005). Cuaderno FIRP S366C Emulsiones asfálticas. Mérida, Venezuela: Universidad de los Andes, Facultad de Ingeniería, Escuela de Ingeniería Química.

View in (Google Scholar)

3. Gabela Berrones, D. H. (2013). Plan de mantenimiento de la carpeta asfáltica de la sección del paso lateral de Ambato comprendida entre Huachi Grande $y$ el redondel del terremoto(Bachelor's thesis, QUITO/PUCE/2013).

View in (Google Scholar)

4. Crespo, S. (2010). Materiales de construcción para edificación y obra civil. Editorial Club Universitario. Alicante, España.

View in (Google Scholar)

5. Repositorio.puce.edu.ec/bitstream/handle/22000/6030/.INGENIERIA CIVIL. (ABRIL de 2010). Obtenido de COLOCACION DE RELLENO COMPACTADO:

View in (PDF)

6. Avelino, L., \& Fabián, B. (2016). Proceso Constructivo Del Palacio Municipal Del Cantón Santa Elena (Bachelor's thesis, Universidad de Guayaquil. Facultad de Ciencias Matemáticas y Físicas. Carrera de Ingeniería Civil).

View in (Google Scholar)

7. González Fernández, J. (2016). Estudio de alternativas para la construcción de firmes permeables. View in (Google Scholar)

8. Fonseca, A. M. (1999). Ingeniería de pavimentos para carreteras. Ciencia e Ingeniería Neogranadina, 7, 7992.

View in (Google Scholar)

9. Rodríguez, A. P. (Ed.). (1998). Periodismo de investigación. Diputación de Pontevedra.

View in (Google Scholar)

10. Pérez Pérez, I., Vázquez Santana, F., Navarro Gamir, V., Medina Rodríguez, L., \& Romana García, M. (2000). Propiedades mecánicas de las capas de base y subbase construidas con materiales granulares en los firmes de carreteras. In Simposio de Carreteras y Aeropuertos (6a․ 2000. La Habana). Editorial Universitaria (La Habana).

View in (Google Scholar)

11. Meza, M. I. Z., Veliz, E. A. R., Mendoza, C. A. V., Delgado, R. A. C., \& Ormaza, G. F. (2018). Comparison of studies through laboratory tests to loan material (ballast) of San Jose and AGRE SA quarries treated with asphalt emulsion or cement. International Journal of Physical Sciences and Engineering, 2(2), 50-67.

View in (Google Scholar)

12. Arévalo, O., Cárdenas, B., Suárez, J., \& Gámez, M. (2017). Environmental Training of Students of the Civil Engineering Career The Universidad Técnica De Manabí. International Research Journal Of Engineering, IT \& Scientific Research (IRJEIS), 3(5), 1-11. doi:10.21744/irjeis.v3i5.527

View in (PDF)

Meza, M. I. Z., Veliz, E. A. R., Anchundia, B. A., Lucas, G. C., \& Ormaza, G. F. (2018). Ballast treated with asphalt emulsion, Megarok and San Jose. AASTHO standards. International Journal of Physical Sciences and Engineering, 2(2), 79-87. https://doi.org/10.29332/ijpse.v2n2.154 
13. Rondón, H. A., \& Reyes, F. (2009). Deformación permanente de materiales granulares en pavimentos flexibles: estado del conocimiento. Revista Ingenierías Universidad de Medellín, 8(14), 71-94.

View in (Google Scholar)

14. Martínez Balarezo, P., \& Navarrete Cahamorro, C. (2007). Recuperación de asfaltos nacionales envejecidos (Bachelor's thesis, SANGOLQUÍ/ESPE/2007).

View in (Google Scholar)

15. De Calderero, R. P., Panchana, C., \& Lectong, D. M. (2018). Use of Concrete Debris. IJPSE, 2(1), 1-12.

View in (Google Scholar)

16. Sánchez, L. K. M., Hernández, E. H. O., Fernández, L. S. Q., \& Párraga, W. E. R. (2018). Determination of Physical and Mechanical Properties of Quarries Dos Bocas Mouths and Mine Copeto for High Resistance Concretes. International Research Journal of Engineering, IT and Scientific Research (IRJEIS), 4(2), 33-40.

View in (Google Scholar) 


\section{Biography of Authors}

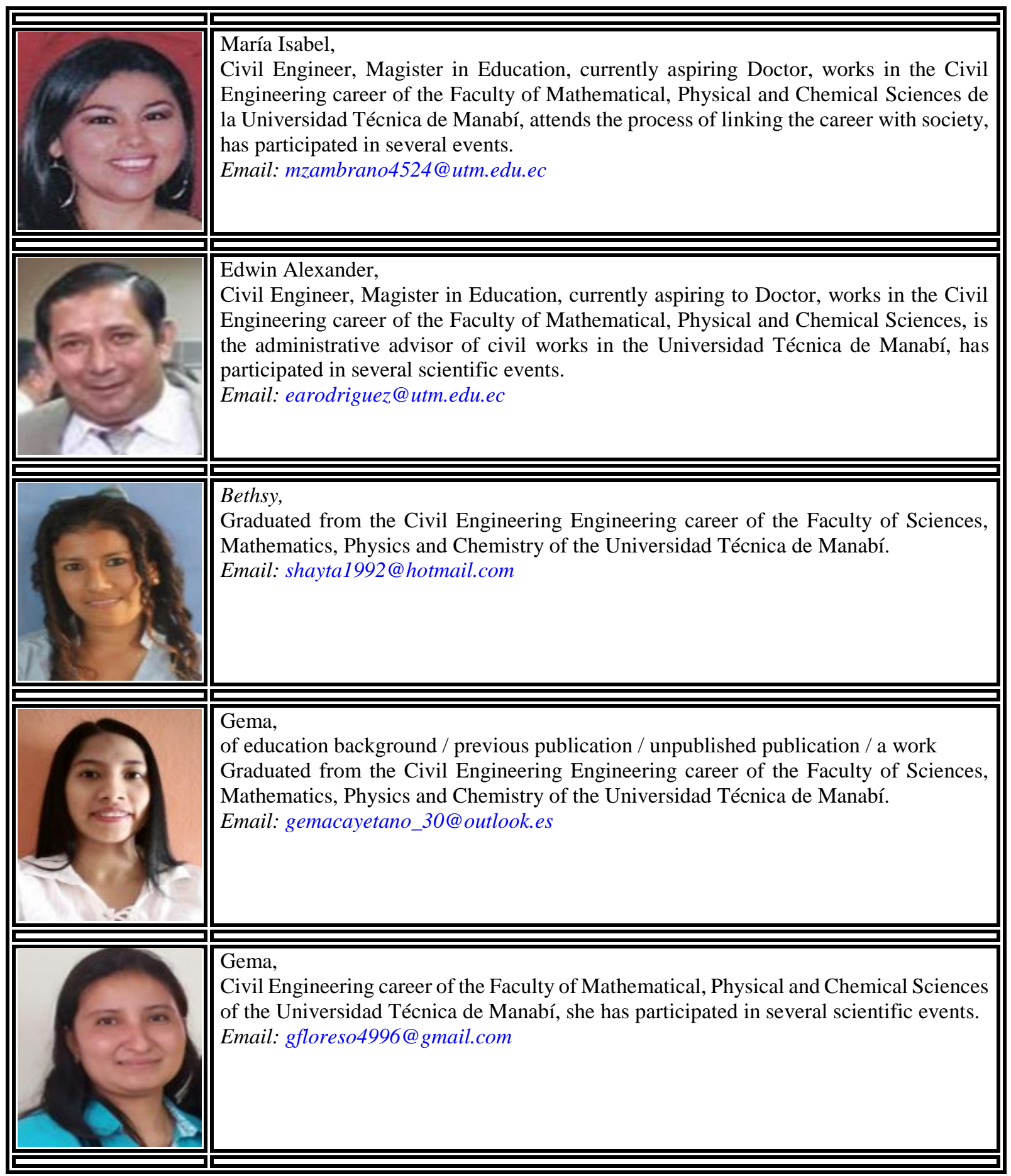

Meza, M. I. Z., Veliz, E. A. R., Anchundia, B. A., Lucas, G. C., \& Ormaza, G. F. (2018). Ballast treated with asphalt emulsion, Megarok and San Jose. AASTHO standards. International Journal of Physical Sciences and Engineering, 2(2), 79-87. https://doi.org/10.29332/ijpse.v2n2.154 